\title{
Integration of Tactical - Medium Range UAV and Catapult Launch System
}

\author{
Zoran Novaković ${ }^{1)}$ \\ Zoran Vasić ${ }^{1)}$ \\ Ivana Ilić $^{1)}$ \\ Nikola Medar ${ }^{1)}$ \\ Dragan Stevanović ${ }^{1)}$
}

\begin{abstract}
In this paper the selection of appropriate UAV catapult launch system from the supply on the world market for existing tactical - medium range Unmanned Aerial Vehicle (UAV) in the Serbian Army is analyzed. A special emphasis was placed on UAV structure strenght at longitudinal accelerations direction which are exposed onto the launch ramp of the catapult. In addition, UAV accommodation to the catapult launch carriage is analyzed. The ultimate goal of this analysis is to define the necessary changes to the structure of the existing UAV in order to successfully integrate it with the selected catapult launch system.
\end{abstract}

Key words: unmanned aerial vehicle, launching ,launching device, catapult, system analysis, system integration.

\section{Introduction}

$\mathrm{T}$ HE development of unmanned aerial vehicle (UAV or aircraft) introduces a new term: unmanned aerial system (UAS) which is considered a hybride system. UAS comprise UAVs (one or more), ground control station (GCS), data processing system (DPS), launch and recovery system. Each of these subsystems is being developed in several directions, so that the number of possible combinations of hybrid UAS definition grows significantly.

The need for UAV catapult launch arose for the following reasons. First, UAV catapult launching eliminates requirements for a take-off path. This is a matter crucial importance in the combat conditions when the availability of the runway is very uncertain. Further on, the propellers, being of fixed pitch, would have to be designed for the best performance for take-off. This would severely compromise the performance of the aircraft in flight, [1]. In addition, UAV take-off from the runway requires additional fuel capacity which increases the weight of the aircraft.

Several systems of launching devices (LDs) for unmanned aerial vehicles have been developed so far. Existing LDs could be grouped into six categories: (1) Pneumatic, (2) Hydraulic, (3) Bungee cord, (4) Kinetic Energy, (5) Electromagnetic, (6) Rocket Assisted Take-off (RATO) and other methods, [2-4].

During their use, the advantages and disadvantages of each type of individual LDs were recognised. This led to the conclusion that an LD must be lightweight, must be able to be operated with minimal personnel, and must have a small storage volume. These factors need to be considered and incorporated into the conceptual design of LDs. Also, the UAV launching device must have the possibility to be set up and launch a UAV within fifteen minutes, [3]. The important factor is the purchase price and the cost of LD maintenance, which is perhaps crucial to the military budget.

All of the above-mentioned concepts, regardless of their relative advantages and disadvantages, are in the operational use in armed forces of a number NATO countries. They are used in those situations when their advantages come to the fore.

\section{UAV launching device selection}

The launching device's main task is to hand over to UAV the previously accumulated energy in its system, so that the $\mathrm{UAV}$, at the time of leaving the catapult, has a speed of at least $15 \%$ greater than the stall speed for a given configuration of the UAV. To have a successful take-off, the UAV should have sufficient lift force, after the instant of leaving the catapult when its own driving propeller achieves stable flight take over, [4].

Table 1. List of LD essential requirements, [3]

\begin{tabular}{||c|c||}
\hline Final Launch Velocity & Launching Angle Range \\
\hline Maximum Take-off Mass & Launching Remote Control \\
\hline Operational Temperature Range & Set Up Time $<15$ minutes \\
\hline LD Mass & LD Disassembling for storage \\
\hline $\begin{array}{c}\text { Maximum Length of the } \\
\text { Launch Envelope }\end{array}$ & Number of the Set Up Personnel \\
\hline Acceleration at Launch $\leq 10 \mathrm{G}$ & $\begin{array}{c}\text { LD Safety, Reliability and easiness } \\
\text { to operate }\end{array}$ \\
\hline
\end{tabular}

According to their launch performance pneumatic (or hydraulic) LDs are perhaps the best because they have a huge catapult's launch power and because they can launch multiple types of UAV (reconnaissance, aerial target) designed for

\footnotetext{
1) Military Technical Institute (VTI), Ratka Resanovića 1, 11132 Belgrade, SERBIA

Correspondence to: Zoran Novaković; e-mail: novakoviczoca@gmail.com
} 
different missions. They are characterized by a relatively uniform acceleration along the launch rail. The disadvantage of this type of LDs is the complexity of their construction, which reduces their reliability. The purchase price of pneumatic (or hydraulic) LD is relatively high compared to other LD concepts, as well as higher maintenance costs.

RATO (Rocket Assisted Takeoff) launching device is characterized by nearly zero length launch ramp and relatively higher level of acceleration. This is the most reliable drive for the UAV launch in extreme environmental conditions, for higher mass of $500 \mathrm{~kg}$ UAV and in conditions of scarce space to launch (boat deck). However, rocket launch has the disadvantage that the rocket bottle is rejected from UAV $(2 \div 3)$ seconds after the start, which is unacceptable from the ecological standpoint. Rocket bottles must be stored in separate areas in the same conditions as explosive. This is inconvenient as it imposes additional costs and liabilities. In addition, the rocket-powered launch reveals a position that is unfavourable in combat conditions, [3].

Bungee catapult systems employ the characteristics of stored energy within high powered, highly elastic bungees to launch UAV. Concept of LD with elastic cords is characterized by the simplest design structure in relation to other concepts of LDs. Because of its simple construction they have the lowest purchase price and the lowest cost of maintenance. Generally, bungee catapults are considered as LDs of less launch power (max. take-off weight 50 to $55 \mathrm{~kg}$ ), [3], except the one that is in operational use in NATO and that stands out for its launch performance (take-off weight $140 \mathrm{~kg}$, take-off speed $34 \mathrm{~m} / \mathrm{s}$ ). The disadvantage of bungee catapult is the initial ,jerk" that can unfavourably affect the sensitive payload of UAV, but it has been overcome successfully by additional fixing equipment inside the aircraft, [1].

When choosing a catapult for Serbian army (regardless of whether it has been purchased or produced) all the criteria set out in Table 1 must be primarily met, in accordance with the characteristics of UAV (maximum launch velocity, maximum launch weight, maximum mean acceleration in the axial direction that UAV withstands). We should endeavour to have catapult selection being based on the multi catapult, which will provide the possibility to launch the currently existing UAVs as well as UAVs that will eventually be the future home development.

The launch parameters of PEGAZ (PEGASUS) UAV:

- Max take-off mass:

- Max take-off speed: $250 \mathrm{~kg}$, require LD with appropriate launch performance and solution should be sought in the selection of:

- Pneumatic Catapult,

- Hydraulic Catapult,

- Hybrid Hydraulic-Pneumatic Catapult,

- Rocket Assisted Take-off (RATO).

From the current range of the UAV LDs in the global market, $[2,5,6]$, which meet the criteria set out in the Table 1 , for PEGAZ, the following UAV LDs could be taken into consideration:

1. MDS HERCULES pneumatic launcher (England)

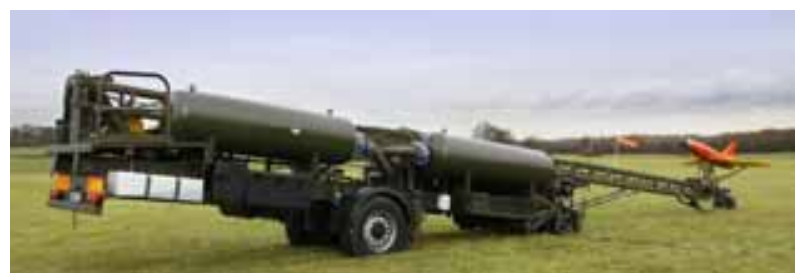

Figure 1. MDS HERCULES pneumatic launcher with aerial target BANSHEE
- Max UAV launch mass, [7], [2]..... $250 \mathrm{~kg}$

Max UAV launch speed. $55 \mathrm{~m} / \mathrm{s}$

2. Aries RO-01 or Aries ALPPUL LP-02 pneumatic launcher (Spain)

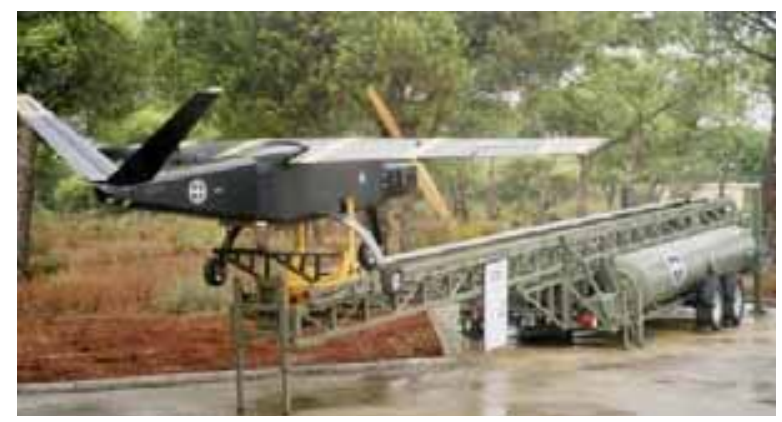

Figure 2. Aries RO-01 pneumatic launcher with UAV SIVA

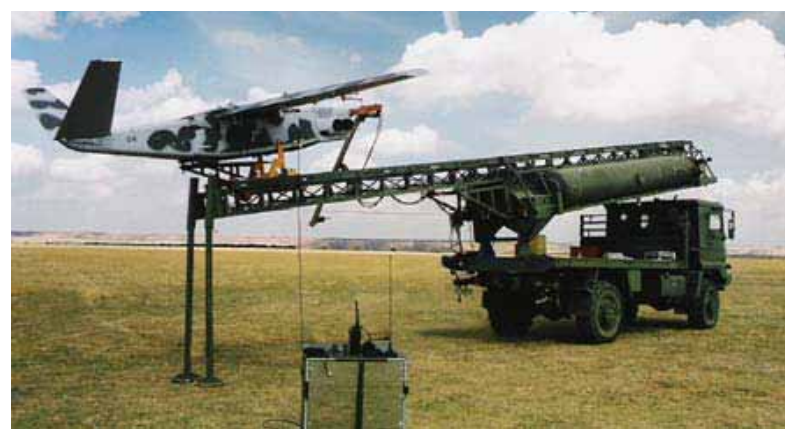

Figure 3. Aries ALPPUL LP-02 pneumatic launcher with UAV SIVA

- Max UAV launch mass, [8], [2].........................360 kg

- Max UAV launch speed. $34 \mathrm{~m} / \mathrm{s}$

3. ESCO-Zodiac HP-3407 hydraulic-pneumatic launcher (USA)

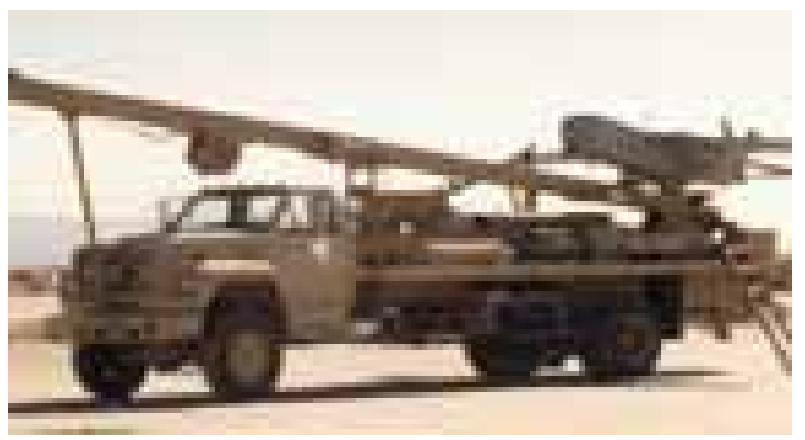

Figure 4. ESCO-Zodiac launcher HP-3407

- Max UAV launch mass, [9], [2] ...........................340 kg

- Max UAV launch speed.....................................33 m/s

4. ARCHER hydraulic launcher (Switzerland)

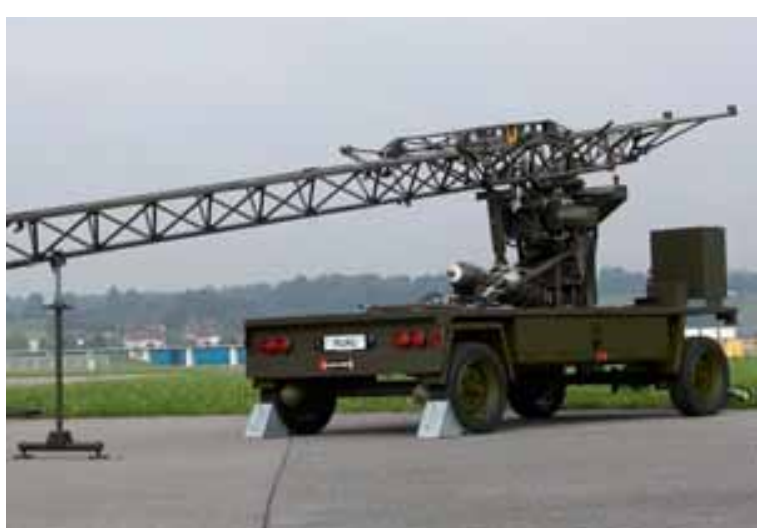

Figure 5. ARCHER hydraulic launcher 
- Max UAV launch mass, [10], [2]...................320 kg

- Max UAV launch speed. $34 \mathrm{~m} / \mathrm{s}$

5. Launching of PEGAZ UAV by rocket assisted take-off catapult should be taken into consideration only if none of the above launchers meet the requirements, (Table 1.).

\section{Analysis of UAV structure strength onto the launch ramp of the catapult}

In the selection of catapult for the aircraft PEGAZ UAV, the first step is to check the strength of the UAV/s existing structures during the acceleration on the launch ramp of the catapult. In addition, it is necessary to check the sensitivity of UAV payload and its fastening inside UAV, but this analysis is beyond the scope of this paper. The actual analysis is performed according to the available acceleration profiles of ARCHER ("RUAG"-Switzerland), Fig.6, launcher and ALPPUL LP-02 ("ARIES" Spain), Fig.7.

Speed/Acceleration profile Fig.6, is relating to UAV RANGER launch with the launch parameters:

- Launch mass...

- Launch speed. $(220 \div 275) \mathrm{kg}$ $(21 \div 38) \mathrm{m} / \mathrm{s}$

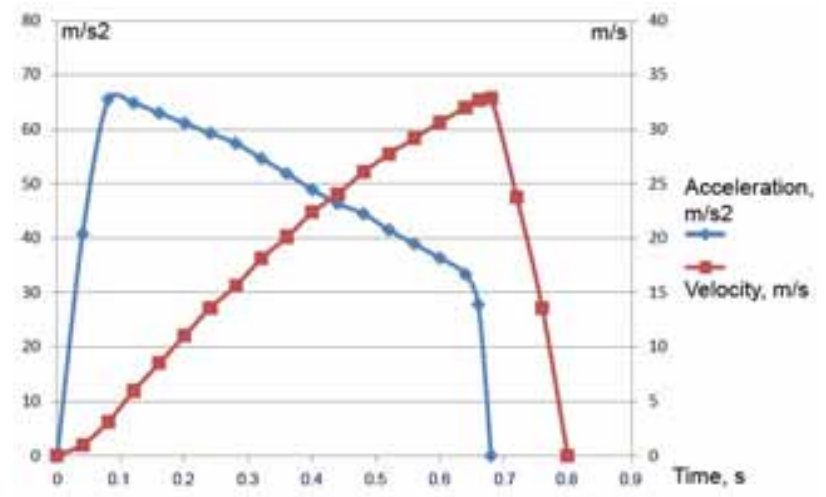

Figure 6. Speed/Acceleration changes onto the catapult ARCHER ramp

Speed/Acceleration profile Fig.7, is relating to UAV SIVA launch with the launch parameters:

- Launch mass.. $300 \mathrm{~kg}$

- Launch speed $33.6 \mathrm{~m} / \mathrm{s}$

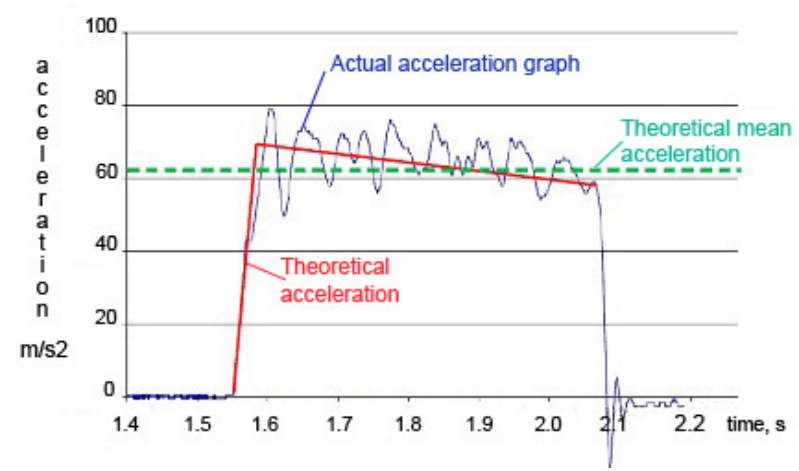

Figure 7. Speed/Acceleration changes onto the catapult ALPPUL LP-02 ramp

Aircraft RANGER mean acceleration on ARCHER launcher rail is close to $5 \mathrm{~g}$, while the mean acceleration of aircraft SIVA on ALPPUL LP-02 launcher is around 6g. It is evident that the launch speeds on both diagrams are practically the same, about $33 \mathrm{~m} / \mathrm{s}$, wherein the launch mass of aircraft SIVA is higher for approximatelly $50 \mathrm{~kg}$ in comparisson to the launch mass of RANGER aircraft. It can be concluded that a lower level of mean acceleration from $1 \mathrm{~g}$ on ARCHER catapult is the result of the differences in aircraft launch mass $(\sim 50 \mathrm{~kg})$.

Since the launching parameters of PEGAZ UAV are closer to launch parameters of RANGER UAV, for this calculation it could be adopted that the acceleration profile (Fig.6) is more credible in comparisson to the acceleration profile (Fig.7). Regardless of the fact that the launch speed is $\sim 33 \mathrm{~m} / \mathrm{s}$, Fig. 6 , (much higher than $25 \mathrm{~m} / \mathrm{s}$, which requires PEGAZ UAV), one can expect a similar level of acceleration when the PEGAZ UAV is launched with the ARCHER catapult. This conclusion should not reduce the quality of ALPPUL LP-02 catapult, as the acceleration profile Fig. 7 refers to the heavier aircraft in relation to the acceleration profile Fig.6.

\section{Necessary changes on PEGAZ structure for catapult integration}

PEGAZ UAV airframe is designed as monoplane, highwing with fuselage nacelle and two tail booms with one horizontal tail and two vertical tails. Aerodynamic scheme with pusher propeller enables safe maintenance and operation before and after flights without the dangerous contact with rotating propeller. The aerodynamic scheme enables payload and mounting of equipment into fuselage nose section.

PEGAZ UAV airframe is made of modern composite materials. Sandwich composite panels are used for airframe parts, with complex shapes in the outer UAV skins and for simple internal structure as well. There are numerous local stiffeners made of laminated fabrics and laminated wood plates at the points of concentrated loads. Original project design defined UAV airframe according to the dominated flight loads in the flight envelope, and in accordance with extreme loads that can be developed during landing on UAV landing gear and parachute landing, in the case of an emergency. First phase of UAV airframe conceptual design does not have tactical and technical requirements for take-off using catapult system or landing using arrester hook or air bag. In other words, design of parts, assemblies and the whole UAV airframe is dimensioned according to aerodynamic and inertial loads that are developed during the flight.

\section{Fuselage nacelle design characteristics}

Fuselage nacelle together with central part of wing makes one-part technological and constructive assembly. Fuselage nacelle is made of several sections, such as:

- Nose front fuselage section with keelson assembled for mounting of nose landing gear, avionics and part of hydraulic brake installations.

- Front central fuselage section is dedicated to embedding the UAV flight navigation equipment, and to mounting the reconnaissance equipment.

- Central fuselage section is used for embedding the front fuel compartment and part of hydraulic brake installations.

- Central fuselage with central part of wing section, part and starboard, is used for embedding the integral fuel tanks and for the attachment of fittings for tail booms and outer wing assemblies.

- Rear central fuselage section is used for embedding the rear fuel compartment and the parachute compartment for emergency landing, and for attachment fittings for main landing gear composite bar spring.

- Rear fuselage section is used for UAV engine and engine equipment.

Fuselage sections and UAV avionics attachment that meet aircraft weight and balance, define internal UAV arrangement. Internal UAV structure is made of composite sandwich panels (laminates with foam core) and appropriate 
reinforcements at the points where the concentrated loads are distributed. There are seven frames and two wing ribs at each wing side in fuselage nacelle (Fig.8).

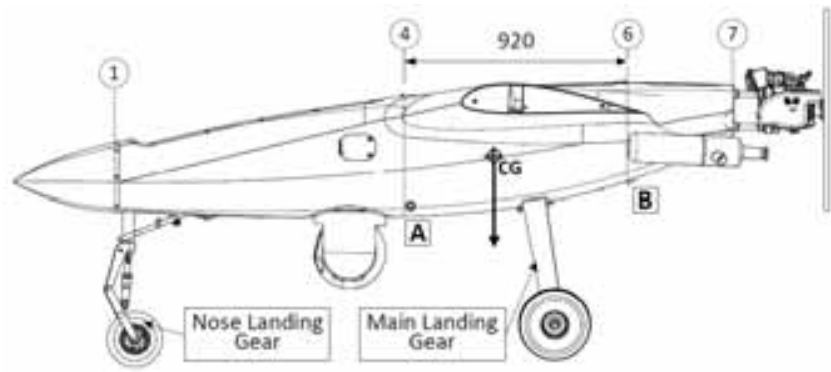

Figure 8. PEGAZ side layout (view without wing, tail booms and tail units)

Fuselage nacelle consists of four composite stringers spreading along the whole fuselage, from nose frame (Frame 1) to firewall frame (Frame 7). Stringers (longeron type) with trapezoidal shapes in cross section are made of foam core and two layers of glass fabrics. Positions of stringers in fuselage cross section are chosen in a way that fully encompasses large fuselage openings, which reinforces fuselage skin together with skin doublers. Fuselage frames are cut in the points of stringers' interconnections.

Fuselage cross section is hexagon-shape having horizontal upper and lower skins. Lateral skins of fuselage cross sections do not have vertical sides. These complex shapes seriously complicate integration of added structure reinforcement intended to receive take-off catapult driven loads, avionics equipment units, and payload into UAV airframe.

There is the opening in the lower fuselage skin allowing nose landing gear movement during extension and retraction. There is circular opening between frame 3 and frame 4 for attachment of gimbaled optoelectronic payload set. There are two hard points for attachment of main landing gear composite spring bar, just behind the main fuselage to wing bulkhead (frame 5). Main landing gear composite spring bar is attached to modified lower fuselage skin by attachment fittings and bolts. Attachment fittings enable freely elastic deformations of composite spring bar during landing, absorbing vertical UAV energy (Fig.9). The design of fuselage for landing gear attachments could not provide robust receiving of longitudinal loads induced by catapult system. That way the landing gear attachment points are not taken into consideration for receiving catapult take-off loads.

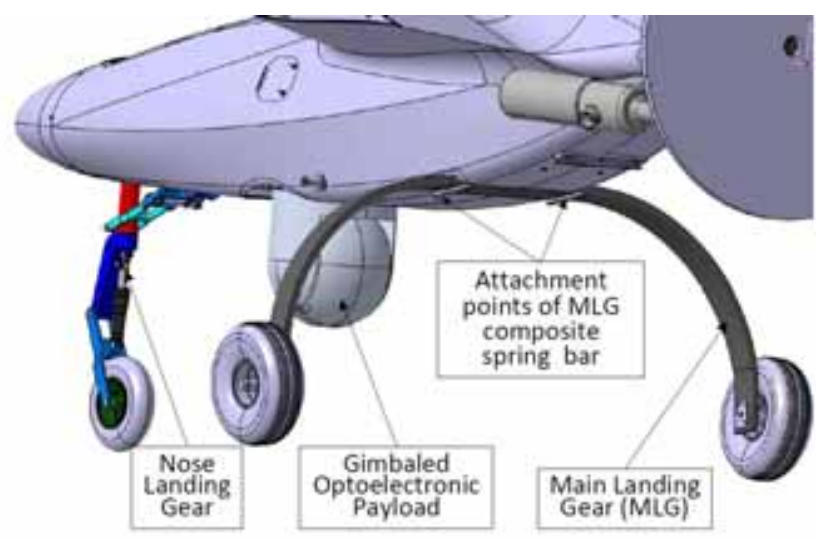

Figure 9. Lower part of UAV fuselage with landing gears and optoelectronic payload

Other UAV airframe assemblies (outer trapezoidal wings, tail booms, horizontal and vertical tails) are made of modern sandwich-type laminated composite materials with appropriate reinforcements at the points where the concentrated loads act the airframe, [11-13].

\section{Analysis of possible locations of airframe reinforcement and integration with catapult system}

The optimal location for UAV structure and catapult launch carriage interface unit must be chosen and designed carefully. Fuselage nacelle is relatively long in comparison to the whole UAV length, so the first solution for interface attachment fittings, positioned close to the first and last fuselage frame, was excluded from further consideration because the catapult launch carriage would be, in that case, too long and cumbersome. The two central fuselage frames, fourth and sixth, were chosen as an acceptable solution for fuselage to catapult launch carriage attachment and interface unit.

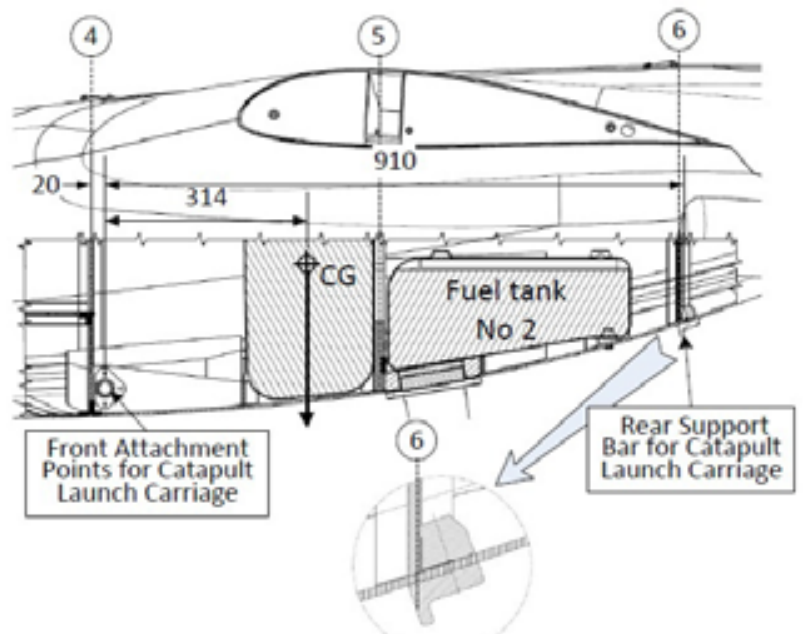

Figure 10. Fuselage internal structure layouts with catapult launch carriage supports

Frame four of fuselage nacelle is used as the rear support of the gimbaled optoelectronic payload platform, in the lower part of the frame, and as the vertical support of two front emergency parachute brackets, in the upper part of the frame. According to the original design, frame is made of $5 \mathrm{~mm}$ light foam core and four glass fabric plies, two from each side, and with local reinforcements made of laminated wood plates at the areas where the concentrated load acts. Actual modification of the frame meant additional cutting of the frame in the lower area where the stringers and new-added main wood support with bushing go through the frame (Fig.11). Main wood support with bushing is the main structural part that receives the main longitudinal load generated by catapult launch system.

Frame six of fuselage nacelle is made of light foam core and glass fabrics. Frame is used as the rear support of the two rear parachute brackets, in the upper part of the frame. Rear support is designed to receive vertical loads (along z-axis) at the frame plane, and not along the other axis. Frame modification meant embedding of the new-added counterpart support made of laminated wood plate at the place where the outer catapult launch carriage support is located. Exterior catapult launch carriage support is made of tetrafluoroethylene transversal bar with "L" cross section and the same length as its internal counterpart support made of laminated wood reinforced with glass fabrics. Mechanical connection of outer support and inner counterpart support is made by three bolts.

Chosen solution for connnection of fuselage nacelle and catapult launch carriage system at the frame four and six is optimal in the sense of meeting different contradictory 
requirements related to take-off by catapult system, $[14,15]$ :

- Design solution enables production of lighter, shorter and compact-made catapult launch carriage assembly,

- Center of gravity (CG) of the whole UAV is located almost at the midpoint between the two supports,

- Fuselage nacelle and catapult launch carriage interconnection does not make any interference with main landing gear spring bar and its bolt connections to the frame structure. Main landing gear spring bar to fuselage structure attachment is designed for vertical loads generated during landing and not for loads longitudinally distributed along the frame nacelle generated by catapult system.

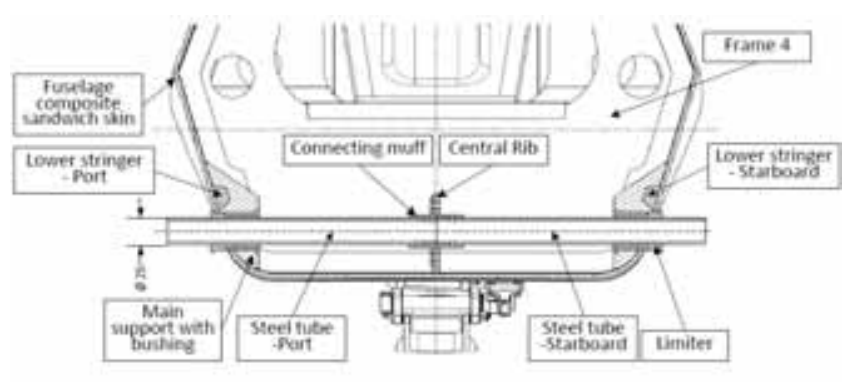

Figure 11. Redesigned structure elements at front catapult launch carriage support

Main (front) catapult launch carriage support at the frame four of the fuselage nacelle is designed for receiving the horizontal and vertical loads (Fig.11). Conceptually, the main support is designed as one transversal steel tube which is actually made of two tubes, port and starboard, connected by one connecting muff at the fuselage symmetry plane (center line). Diameter of the tubes is $25 \mathrm{~mm}$ and tube wall thickness is $3 \mathrm{~mm}$. At the fuselage center line, the axial movement and rotation of the tubes are constrained by two bolts and connecting muff. Connecting muff is attached to new-added longitudinal fuselage rib at the fuselage center line by bolt connections. The main vertical and horizontal loads are transferred from the two tubes to the fuselage structure through the two main supports with bushing, port and starboard, made of laminated wood plate reinforced by glass fabrics. Two main supports with bushing are shaped to align to the inner surfaces of the fuselage skins and to the lower trapezoidal-shaped fuselage stringers. Main supports have the hole close to the frame four. Metal bushing is embedded into the main support hole. Inside diameter of the metal bushing is made with high tolerance to the outside diameter of the steel tube. Metal bushing (on the port and starboard side) has flange that acts as an axial limiter protecting from hard impact of catapult launch carriage steel arms to fragile UAV composite skin and its consecutive damage.

Main landing gear conception and its position to the catapult launch carriage supports require additional design efforts related to resolving the kinematics of the catapult launch carriage arms that will avoid collision of landing gear, fuselage structure, optoelectronic payload, and engine propeller.

\section{PEGAZ Strength Analysis}

In the case of take-off using catapult launching device the strength of structure of the aircraft PEGAZ UAV must be taken into consideration. All joints of main parts of the UAV structure and all the elements that have attached concentrated mass have to be designed for a load case when inercial force is applied, in direction of $\mathrm{x}$ axis of the UAV.

The value of inertial force is calculate by following:

$$
F_{i n}=n_{x} \cdot g \cdot m
$$

where $n_{x}=8$ represents the factor of inertial load in direction of $\mathrm{x}$ axis, and $\mathrm{m}$ represents mass of the vehicle.

Besides that, the ultimate factor must be taken into consideration, $j=1.5$. For all vital joints the ultimate factor has to be multiply by the joint factor, $j_{v}=1.2$.

To calculate strength of the joint between the UAV and catapult launching device (for maximum mass of the UAV $\mathrm{m}=250 \mathrm{~kg}$ ) the value of the force that is introduced to the joint is

$$
F_{x}=j \cdot j_{v} \cdot F_{i n}=35316 \mathrm{~N}
$$

This force is applied in the center of gravity, aligned with $\mathrm{x}$ axis of $U A V$, in postive direction of the axis.

Force, $F_{x}$, is reduced to the main catapult launch carriage support, at the frame four of the fuselage nacelle, which causes bending moment My with intesity:

$$
M_{y}=F_{x} \cdot 0.214=7558 \mathrm{Nm}
$$

Front support is receiving all horizontal load, $F_{x}$, while moment $M_{y}$ is defined as a couple of vertical forces (Fig.12) that are accepted by front and rear support points:

$$
F_{z}=\frac{M_{y}}{0.9}=\frac{7558}{0.9}=8398 \mathrm{~N}
$$

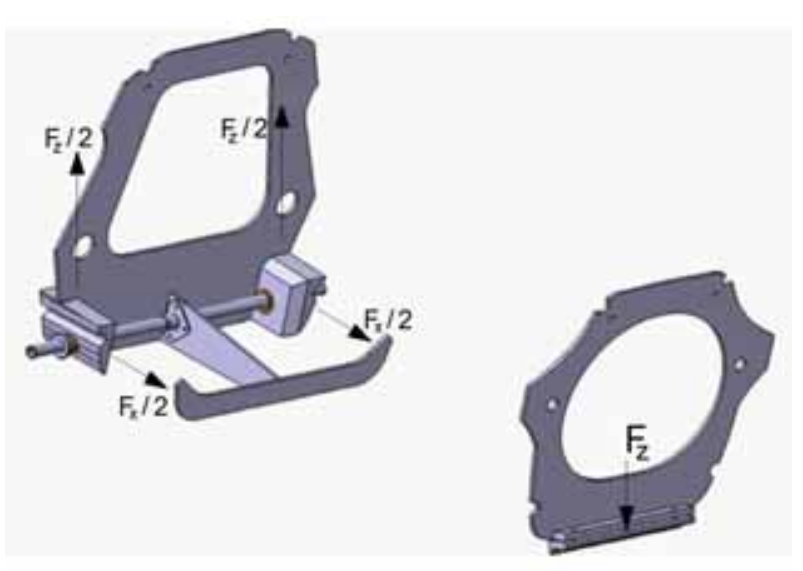

Figure 12. Forces acting on the catapult launch carriage supports

Strength calculation of attachment of the catapult launch system to UAV is done by using classical engineering methods. Reserve factor, which represents the ratio of ultimate stress for material that was used and stress in the element of structure, is greater than 1 on all elements for conection of the fuselage nacelle and the catapult launch system, at the frame four and six.

\section{Launch Carriage Interface Requirements}

The main task of launch carriage interface is to support the UAV during the launching phase. Also launch carriage mechanical interface is essential in the System Preparation and Preflight State until launch. The UAV is held in one place during the preflight operations, including checks and engine ground run. At the launch phase, the UAV is pushed to flight speed and at the end of the launch phase, the UAV leaves the launcher in the flight direction.

\section{Mechanical Interface Requirements, [10]}

Mechanical interface operating is sequentially distinguished in three phases:

- Loading the UAV onto the launcher.

- The UAV is held in static position with only gravitational 
forces and also combined with the engine thrust. This requires longitudinal fixation of the UAV in both directions.

- The UAV is accelerated by the launcher and slides out of the guidance at the end of the launch. Longitudinal fixation of the UAV only in backward direction is required.

\section{Physical Requirements}

\section{Dimensions}

The dimensions of the interfacing elements of the PEGAZ UAV (nominal weight of $250 \mathrm{~kg}$ ) are given in Figures 10 and 11.

\section{Forces}

- Force for acceleration of PEGAZ UAV: $\max 22073 \mathrm{~N}$, corresponding to $9 \mathrm{~g}$ with $250 \mathrm{~kg}$ PEGAZ UAV mass, acting in direction of the rail. This force to be transferred by the forward hooks. The rearward support serves for guidance of the UAV.

- Weight force of the PEGAZUAV: $\max 2500 \mathrm{~N}$ with respect to ground vertical.

- Center of PEGAZ Gravity Range: $\max 350 \mathrm{~mm}$ in back of the forward hook.

\section{Conclusion}

The proposed redesign of PEGAZ UAV enables it to be launched from any catapult whose max acceleration on the launch rail is up to $8 \mathrm{~g}$. The launch parameters of PEGAZ UAV (max launch speed $25 \mathrm{~m} / \mathrm{s}$, max launch mass $250 \mathrm{~kg}$ ) are less demanding than the launch parameters of RANGER UAV or SIVA UAV. This confirms that the launch catapult performance of ARCHER or ALPPUL LP-02 makes it possible to launch PEGAZ succesfully. It is realistic to expect that PEGAZ UAV will be exposed to the maximum of $5 \mathrm{~g}$ average acceleration on the launch rail of any of these two launchers.

Also, the proposed redesign of PEGAZ UAV and set requirements for launch carriage interface enable launch carriage adaptation on launchers ARCHER or ALPPUL LP02 according to modular dimensions of PEGAZ UAV.

\section{References}

[1] AUSTIN,R.: Unmanned aircraft systems:UAVS design, development and deployment, John Wiley \& Sons Ltd, Chichester, West Sussex, United Kingdom, 2010.

[2] NOVAKOVIĆ,Z., MEDAR,N.: Lansirni sistemi bespilotnih letelica, Podaci o naoružanju, Podaci o naoružanju-Faktografske sveske, Vojnotehnički institut, Beograd, 2015, Vol.XXXVIII, No.156, ISSN 1820-3426, ISBN 978-86-81123-76-8.

[3] FRANCIS,J.: Launch System for Unmanned Aerial Vehicles for use on RAN Patrol Boats, Final Thesis Report 2010, SEIT, UNSW@ADFA

[4] NOVAKOVIĆ,Z., MEDAR,N.: Design of UAV Elastic Cord Catapult, OTEH 2014, $6^{\text {th }}$ International Scientific Conference on Defensive Technologies OTEH 2014, 09-10. October 2014, Belgrade Serbia, ISBN 978-86-81123-71-3, pp.141-150.

[5] Jane's.: Unmanned Aerial Vehicles and Targets, 2007, Issue 29, Launch and Recovery, Chapter.

[6] Unmanned Vehicle Handbook, Issue 21, SHEPHARD 2013. pp. 164,165 .

http://shephardftp.co.uk/digital_editions/sample\%20pages/UVH 21 sa mple/index.html\#/16/

[7] Catalogue of "Meggitt Defence Systems" firm, http://www.meggittdefenceuk.com/PDF/Hercules\%202014_App\%20M od\%201.pdf

[8] Catalogue of "Aries Ingenieria y Systemas" company, ALPPUL LP-02 pneumatic launcher, http://www.ariestesting.com/solutions-byapplications/unmanned-aerial-systems/uav-launchers/

[9] Catalogue of "Zodiac Aerospace" company, http://s76586.gridserver.com/downloads/documents/hp3003.pdf

[10] Catalogue of "RUAG Aerospace" company, http://ofp.gamepark.cz/ hosted/swissteam/Pictures of Swissmod/arche r flyer.pdf

[11] NIU,M.C.Y.: (1992). Composite Airframe Structures, Conmilit Press Ltd., Hong Kong

[12] ARONSSON,A.: (2005). Design Modeling and Drafting of Composite Structures, Master thesis, Lulea Univerisity of Technology, 2005:060 CIV, ISSN: $1402-1617$.

[13] WILlingER,M.: Industrial Development of Composite Materials: Towards a Functional Appraisal, Composites Science and Technology, 1989, 34, pp.53-71.

[14] NIU,M.C-Y.: Airframe Structural Design, Practical Design Information and Data on Aircraft Structures, Conmilit Press Ltd., 1988.

[15] STINTON,D.: The Design of the Aeroplane, BSP Professional Books, Oxford, 1983.

[16] BRUHN,E.F.: Analysis and Design of Flight Vehicle Structures, TriState Offset Company, 1973.

[17] STANAG-4671

\title{
Integracija taktičke bespilotne letelice srednjeg doleta i katapultskog lansirnog sistema
}

\begin{abstract}
Uovom radu se analizira izbor odgovarajućeg katapultskog lansirnog sistema bespilotnih letelica (BL) za postojeću BL srednjeg doleta u srpskoj vojsci. Poseban akcenat je stavljen na izdržljivost strukture BL na ubrzanja, kojim je BL iložena duž lansirne rampe katapulta. Dodatno, u radu se analizira prilagođenje BL za njen smeštaj na lansirna kolica katapulta. Krajnji cilj ovih analiza je definisanje neophodnih promena na strukturi postojeće BL da bi se uspešno integrisala sa izabranim katapultskim lansirnim sistemom.
\end{abstract}




\title{
Интеграция тактического бпла средней дальности полёта и катапультирующей пусковой системы
}

\begin{abstract}
В этой статье анализируется выбор соответствующей катапультирующей пусковой системы БПЛА на мировом рынке с поставкой беспилотного летательного аппарата (БПЛА) тактической средней дальности полёта в серб́ской армии. Особый акцент поставлен на прочность конструкции БПЛА в продольном направлении ускорения, которое экспонируется на стартовую рампу катапульты. Кроме того, анализируется размещение БПЛА в запускной карете для катапульты. Конечной целью этого анализа является определение необходимых изменений в конструкции существующего БПЛА, чтобы успешно интегрировать его с выбранной катапультирующей пусковой системой.
\end{abstract}

Ключевые слова: беспилотный летательный аппарат, запуск, пусковое устройство, катапульт, анализ системы, интеграция системы.

\section{Intégration de l'aéronef tactique sans pilote de moyenne portée et le système de catapultage}

\begin{abstract}
Dans ce travail on analyse le choix d'un système de catapultage convenable aux aéronefs sans pilote (BL) pour l'aéronef de moyenne portée qui existe actuellement dans l'Armée serbe. L'accent particulier a été mis sur la résistance de la structure d'aéronef sans pilote aux accélérations auxquelles BL est exposé le long de la rampe de catapultage. En plus dans ce papier on a analysé aussi l'adaptation de BL à son installation sur le chariot de catapulte. Le but final de ces analyses était de définir les changements nécessaires sur la structure de BL actuel pour l'intégrer avec succès au système de lancement de catapultage.
\end{abstract}

Mots clés: aéronef sans pilote, lancement, dispositif de lancement, catapulte, analyse de système, intégration de système. 